\title{
4 \\ Energy and Russian Great Power Post-Crimea
}

\author{
Peter Rutland
}

Vladimir Putin has been in power for 20 years, longer than Leonid Brezhnev. (He was appointed prime minister on 9 August 1999 and president on 31 December 1999.) During that time there have been some important shifts in the balance between the different instruments in Russia’s power projection toolkit.

In the 2000s, the biggest fear in the West was, it seems, the energy weapon. However, Russia's rebuilding of its military power and its demonstrated willingness to use armed force beyond its borders has shifted the balance towards hard power. This began with Russia's invasion of Georgia in 2008 and continued with the annexation of Crimea in March 2014 and the military intervention in Syria in September 2015.

At the same time, changes in global energy markets (the fracking revolution and the rise of China) have changed the equation of risks and rewards in Russian energy exports. Increasing global economic integration left Moscow vulnerable to fluctuations in world markets, and post-Crimea sanctions revealed its exposure to Western interruption of key technologies and financial services. Russia's capacity to wield the energy 'weapon' to advance its interests looks more questionable today than it did in 2008.

There is a curious imbalance between Russia's resurgence as a power on the world stage and its anaemic economic performance and dim growth prospects. This is largely explained by the decisive role that energy plays 
in structuring Russia's domestic political economy. Russia remains very much a 'petrostate', in which energy rent-seekers, in alliance with security forces, have the upper hand over profit-seekers. This is part of a broader pattern in emerging market economies in which 'the middle income trap is in the final analysis a political trap not an economic one'. ${ }^{1}$ Therefore, the main geopolitical importance of energy when it comes to understanding Russia is its role in shaping the behaviour of the Russian power elite. There are some important feedback loops_-both positive and negative- between the domestic political regime of the 'petrostate' and the aspirational international role as an 'energy superpower'.

\section{Russia as an Energy Superpower}

Oil and gas were key to Russia's return to prominence on the international stage in the 2000s, when it became common to refer to Russia as an 'energy superpower'. ${ }^{2}$ The Economist and many other Western publications were fond of cartoons showing the Russian bear sitting astride oil and gas pipelines, gleefully shutting the valves. There was growing concern that Russia was using energy dependency to pressure neighbouring states to accede to Russia's political or economic demands, and to project influence over customer states further afield. Robert Larsson identified 55 instances between 1992 and 2006 when Russia either cut off, or threatened to cut off, energy supplies. ${ }^{3}$ For the Russian elite, too, the term 'energy superpower' was a useful rhetorical device justifying their rule, with the geopolitical utility of energy being expressed in the 2003 Energy Strategy.

There is no question that the raw data show Russia is an energy superpower. Russia is the second-largest producer of natural gas and third-largest producer of oil in the world. In 2016, Russia pumped 11 million barrels of crude oil a day, about 12 per cent of the global supply, placing third

1 Hartmut Elsenhaus and Salvatore Babones, BRICS or Bust? Escaping the Middle Income Trap (Stanford: Stanford University Press, 2017), 107, doi.org/10.1515/9781503604919.

2 The term was used a handful of times in the 1990s, but only came into more widespread usage in the wake of Russia's interruption of natural gas supplies to Ukraine in January 2006. See, Stefan Bouzarovski and Mark Bassin, 'Energy and Identity: Imagining Russia as a Hydrocarbon Superpower', Annals of the Association of American Geographers 101, no. 4(2011): 1-12, doi.org/10.1080/00045608. 2011.567942; Peter Rutland, 'Russia as an Energy Superpower', New Political Economy 13, no. 2 (June 2008): 203-10, doi.org/10.1080/13563460802018547.

3 Robert Larsson, Russia's Energy Policy: Security Dimensions and Russia's Reliability as an Energy Supplier (Stockholm: Swedish Defence Research Agency, 2006). 
after the US and Saudi Arabia. ${ }^{4}$ From 2004 to 2011, it was in second place after Saudi Arabia, before being overtaken by the US due to the fracking revolution. In September 2019, the US became a net oil exporter-for the first time since records began. ${ }^{5}$ Russia remains the world's second-largest oil exporter, supplying about 20 per cent of European oil consumption. As for natural gas, Russia accounts for 20 per cent of global output and holds 25 per cent of proven reserves. Due to the shale gas boom, the US has taken over as the world's top gas producer, but Russia remains the number one exporter, with 15 per cent of the global gas market. ${ }^{6}$ It supplies 25 per cent of the gas used by the EU and 33 per cent of the gas that the EU imports. Coal and nuclear power are also important. Russia is the world's sixth-largest coal producer and third-largest coal exporter, with coal exports tripling over the past decade to about US $\$ 10$ billion per year.

In addition to being a major producer, Russia also serves as a transit country for oil and gas exports to Europe from landlocked Central Asia. The Soviet Union pipeline system connected Kazakhstan, Uzbekistan and Turkmenistan to the Russian Federation network, and it would be two decades before they were able to develop alternative export routes-to China. The 1,800 km long Turkmen-China gas pipeline was opened in 2009 , and the same year saw completion of a 2,300 km oil pipeline from Atyrau in Kazakhstan to Alashankou in Xinjiang. ${ }^{7}$

After the Soviet collapse, Russia found itself in the awkward position of being dependent on pipelines transiting Belarus, Lithuania, Latvia and Ukraine to get its oil and gas to Western markets. Starting in the 1990s, it embarked on an ambitious and costly program to build new pipelines to provide alternative export outlets, preferring routes that transited the Baltic and Black Seas, thereby circumventing Russia's ornery neighbours and hostile countries such as Poland (see Table 4.1). Russia built new oil terminals on its Baltic coast and two pipelines to supply them with

4 'IEA Atlas of Energy: Oil', International Energy Authority (IEA), accessed 20 August 2020, energyatlas.iea.org/\#!/tellmap/-1920537974/0; 'Total Energy Production 2017', US Energy Information Administration (EIA), accessed 20 August 2020, www.eia.gov/beta/international/rankings/\#?cy=2015.

5 In December 2018, the US exported slightly more oil than it imported for the first time (both crude and oil products combined). See, Robert Rapier, 'No the US Is Not a Net Exporter of Crude Oil', Forbes, 9 December 2018, www.forbes.com/sites/rrapier/2018/12/09/no-the-u-s-is-not-a-netexporter-of-crude-oil/\#248425554ac1.

6 'IEA Atlas of Energy: Natural Gas', IEA, accessed 20 August 2020, energyatlas.iea.org/\#!/tellmap/$1165808390 / 0$.

7 Gazprom stopped buying gas from Turkmenistan in 2016 and restarted in April 2019. China buys $40 \mathrm{bcm} / \mathrm{y}$; Russia will buy $6 \mathrm{bcm} / \mathrm{y}$. 
crude oil to avoid dependence on the Ventspils terminal in Latvia and Butinge in Lithuania. ${ }^{8}$ The Nord Stream gas pipeline across the Baltic to Germany became operational in 2011, adding $55 \mathrm{bcm}$ to Russias existing $245 \mathrm{bcm}$ export capacity. Construction began on Nord Stream 2 in 2018, but US sanctions delayed work on the project, which as of August 2020 was 94 per cent complete. ${ }^{9}$

Table 4.1: Key pipeline projects since 2000

\begin{tabular}{|l|l|}
\hline Year* & Operation \\
\hline 2001 & $\begin{array}{l}\text { Baltic Pipeline System (oil) to port of Primorsk on Russia's Baltic coast, } \\
\text { second line } 2012\end{array}$ \\
\cline { 2 - 3 } & $\begin{array}{l}\text { Caspian Pipeline Consortium (oil) from Tengiz, Kazakhstan, to Russian port } \\
\text { of Novorossiisk; lead partners Chevron and Lukoil }\end{array}$ \\
\hline 2005 & Blue Stream (gas) across Black Sea to Turkey \\
\hline 2011 & $\begin{array}{l}\text { Nord Stream (gas) under Baltic Sea from Vyborg to Griefswald, Germany; } \\
\text { second line added 2012 }\end{array}$ \\
\cline { 2 - 3 } & Sakhalin-Khabarovsk-Vladivostok (gas), to feed future LNG export plant \\
\hline 2012 & East Siberia - Pacific Ocean (oil) to China \\
\hline 2014 & $\begin{array}{l}\text { South Stream (gas) across Black Sea to Bulgaria cancelled, instead new } \\
\text { Turkish Stream }\end{array}$ \\
\cline { 2 - 3 } & Power of Siberia (gas) from Yakutsk to China, construction began \\
\hline 2015 & Ukraine connects reverse flow pipeline to import gas from Poland \\
\hline 2018 & Nord Stream 2 (gas) to Germany, construction began \\
\hline
\end{tabular}

* Start of operation, unless otherwise stated.

Russia's success in building these new export pipelines was a major strategic accomplishment of the Putin era. Moscow had the additional goal of deterring Western projects to build new pipelines to bring oil and gas to Europe from the Caspian basin. BP's Baku-Tbilisi-Ceyhan oil pipeline did open in 2005, but more ambitious Trans-Caspian gas projects such as the EU-sponsored Nabucco line have not yet come to fruition. Russia was able to use the ambiguous legal status of the Caspian Sea to block plans to build pipelines across the Caspian to bring Kazakh oil and Turkmen gas to European markets. ${ }^{10}$

8 Margarita Balmaceda, The Politics of Energy Dependency. Ukraine, Belarus and Lithuania Between Domestic Oligarchs and Russian Pressure (Toronto: University of Toronto Press, 2015), 296.

9 Julia Kuznir, 'The Impact of EU Regulations on Nord Stream 2', Russian Analytical Bulletin, 6 June 2019, 9-13; Marco Siddi, 'German Debates and Policies on Russia 2014-17', in EU Members States and Russia, ed. Marco Siddi (Finnish Institute of International Affairs, 2018), 28-40.

10 The littoral states signed a convention on 12 August 2018 in Aktau, Kazakhstan, establishing a 15-mile territorial limit, and allowing bilateral agreements on borders between adjacent and opposite countries. It is too early to say whether this will resolve the conflicts. 
Russia’s energy and metals conglomerates have also aggressively pursued acquisitions of production facilities and distribution networks across Europe, from the Balkans to Britain. The EU tried to use the Energy Charter Treaty (ECT) to mandate third-party access to Russia’s pipelines and the 'unbundling' of large energy companies (i.e. the separation of production and distribution companies). Russia signed the ECT in 1994, but never ratified it, and refuses to comply with its mandates. ${ }^{11}$ Russia is more dependent on energy exports to the EU than the EU is on Russia as supplier, but Russia has more effective leverage because it is a single actor. ${ }^{12}$

Was the West really in fear of the Russian energy weapon in the 2000s, or was it just an easily evoked threat, a substitute for deeper anxietiesabout Russian authoritarianism and imperialism — that could not directly be articulated? After all, Western Europe had been dependent on Soviet oil since the opening of the Druzhba pipeline in 1964, and, despite all the alarms and crises over the next 50 years, at no point was the supply interrupted for political reasons. There were brief disruptions of the gas supply-to Belarus and Ukraine in 2006-07-but these were disputes over the prices in the annual contract, and were limited in time (17 days was the longest interruption) and scope (Bulgaria and Moldova were affected, but none of the major Western customers). ${ }^{13}$ Even after the annexation of Crimea, Russian gas continued to flow across Ukraine. ${ }^{14}$ In 2018, the Stockholm Arbitration Institute awarded Ukraine US $\$ 4.6$ billion in compensation from Gazprom for gas transit fees, minus US $\$ 2$ billion, which Naftohas owed for $5 \mathrm{bcm}$ of gas it had used and not paid for. Soon after, Gazprom appealed the decision and, in 2020, the appeal was rejected.

There is little evidence that Russia gained much from these efforts to wield the 'energy weapon', which often served to alienate the countries on the receiving end and make them seek alternatives to Russia. Trade is a relationship of mutual benefit and dependence between buyer and seller, and use of trade as a 'weapon' can hurt the supplier just as much as the

11 Andrey Kazantsev, 'Policy Networks in European-Russian Gas Relations: Function and Dysfunction from a Perspective of EU Energy Security', Communist and Post-Communist Studies 45, no. 3-4 (2012): 305-13, doi.org/10.1016/j.postcomstud.2012.07.006.

12 Veli-Pekka Tynkkynen, The Energy of Russia. Hydrocarbon Culture and Climate Change (London: Edward Elgar, 2019), 79.

13 Balmaceda, The Politics of Energy Dependency.

14 Due to Nord Stream, Russian gas transit across Ukraine had already fallen from $71 \mathrm{bcm}$ in 2011 to $31 \mathrm{bcm}$ in 2014 . 
customer. The literature on economic sanctions suggest that they are more likely to be effective when they are multilateral, but Russia's efforts have been unilateral. The one exception is their participation in Saudi Arabia's efforts since 2016 to restrain the oil supply (Russia agreed to cut its output by $300,000 \mathrm{~b} / \mathrm{d}$ ) ${ }^{15}$ Using energy as a carrot rather than a stick has not proved any more effective. Twenty years of subsidised energy prices for Belarus (amounting to perhaps 10 per cent of GDP) has not produced a loyal and subservient ally.

The concept of an 'energy superpower' is somewhat contradictory, lumping together two quite distinct logics: that of the energy market and that of military superpowers. Despite its vast wealth (and its spiritual role as the birthplace of Islam), we do not think of Saudi Arabia as a world power (it is even unable to prevail in the war in neighbouring Yemen). It is unusual to see a resource-rich country taking on the attributes of a world power: historically, it was the colonised countries and not their imperial masters who were the resource exporters. Typically, resource-rich countries have not used military power to create empires. Rather, it is usually resourcepoor countries that create empires in order to acquire more resources. The US itself has a rich resource base, but it was its manufacturing industry and not its resource exports that was the backbone of its rise to superpower status. The US began to import oil in the late 1940s, and it was precisely the search for oil that was (and remains) a contributory factor to its willingness to shoulder the superpower role. Russia, of course, is the grand exception: Tsarist Russia was rich in land and resources and exported commodities such as grain and timber, but it created the world's largest empire. The expansionism of the tsars was driven by a concern for security and prestige rather than a search for resources. Likewise, the USSR's quest for empire was not primarily driven by a need for more resources, but by a combination of security fears and ideological fervour. Putin's Russia seems to be reverting to a similar pattern. Unfortunately, it ended badly both for the tsars and the Soviets.

15 James Henderson, 'Russian Oil Production Outlook to 2020', Oxford Institute for Energy Studies, January 2017, www.oxfordenergy.org/publications/russian-oil-production-outlook-to-2020/. 


\section{Russia as a Petrostate: The Domestic Dimension}

Even though Russia may not be an energy superpower, it is still a petrostate, heavily dependent on the production and export of energy. ${ }^{16}$ For most of the past two decades, hydrocarbons have accounted for 25 per cent of Russia's GDP, 60 per cent of exports and 40 per cent of government revenue. ${ }^{17}$ The Russian business cycle was closely tied to fluctuations of the international price of oil, though that relationship has broken down since $2014 .{ }^{18}$ The Russian energy giant walks on two legs: oil and natural gas. Externally, oil export revenues are three times larger than those for gas. But, inside Russia, gas accounts for three times as much energy consumption as oil, being used to heat homes and generate 50 per cent of Russia's electricity. ${ }^{19}$ Gazprom uses its export revenue to subsidise domestic consumers: in 2017 the export price was US $\$ 9.2 \mathrm{mmbtu}$ and the domestic price US $\$ 3.8{ }^{20}$

Russia has vast untapped oil and gas reserves and it has not yet reached peak oil. However, most of Russia's newly discovered fields are located in permafrost zones and many of them are offshore (notably the Sakhalin deposits and the Shtokman gas field in the Barents Sea). The US $\$ 27$ billion Yamal gas field, for example, lies north of the Arctic Circle, and LNG will be shipped out on icebreaker tankers (being built in South Korea). Russia doubled its share of global LNG to 8 per cent in 2018 and wants 20 per cent by $2035 .{ }^{21}$ The Sakhalin 1 project, which commenced in 2003, needed Exxon advanced 3D seismology and horizontal drilling. Other fields require lengthy new pipelines. These factors substantially increase the extraction costs, meaning that the price of oil will have to stay above US\$50 a barrel for

16 Michael Ellman ed., Russia's Oil and Natural Gas: Bonanza or Curse? (London: Anthem Press, 2006).

17 Shinichiro Tabata, 'Observations on the Influence of High Oil Prices on Russia’s GDP Growth', Eurasian Geography and Economics 47, no. 1 (2006): 95-111, doi.org/10.2747/1538-7216.47.1.95.

18 Dmitrii Kuznets, 'Kurs rublia bol'she ne sziazan s kursami na neft' [The rouble exchange rate is no longer linked to oil prices, sanctions are not that terrible], Meduza, 30 November 2018, meduza. io/feature/2018/11/30/kurs-rublya-bolshe-ne-svyazan-s-tsenami-na-neft-sanktsii-ne-strashnyproveryaem-slova-ministra-finansov.

19 Susanne Wengle, Post-Soviet Power. State-Led Development and Russia's Marketization (Cambridge: Cambridge University Press, 2015), doi.org/10.1017/CBO9781139680479.

20 Natassia Astrasheuskaya, 'Gazprom Takes on Chechnya', Financial Times, 11 February 2019.

21 'Russian LNG projects are competitive', Moscow Times, 21 March 2019, www.themoscowtimes. com/2019/03/21/russian-lng-projects-are-competitive-shell-executive-a64913. 
these projects to be commercially viable. ${ }^{22}$ Although oil peaked at US $\$ 140$ a barrel in 2008, the average oil price over 1997-2007 was US $\$ 35$ a barrel, and US $\$ 80$ a barrel in 2008-18. The hefty 60 per cent depreciation of the rouble after 2008 enabled Russia to stay a competitive producer. ${ }^{23}$

Putin embarked on a policy of renationalisation of the oil sector. Stateowned Rosneft acquired Yukos in 2003 and Gazprom bought Sibneft in 2004; and the state increased its stake in Gazprom to 50 per cent in $2005 .{ }^{24}$ Foreign participation was further restricted: Shell was forced to sell their Sakhalin 2 project to Gazprom in 2006 (under pressure from spurious environmental claims), and in 2013 Rosneft bought TNK-BP for US $\$ 56$ billion. Rosneft ended up with 40 per cent of the country's oil output. In return, Rosneft has played an active role in Russia's new foreign policy adventurism. For example, it has loaned more than US $\$ 1.8$ billion to Venezuela, and when the US sanctioned that country in January 2019, Rosneft helped to divert its oil exports to Asia. ${ }^{25}$

The renationalisation campaign saw ownership and control of Russian energy corporations concentrated in the hands of a small circle of individuals close to Putin, such as Igor Sechin (Rosneft) and Aleksei Miller (Gazprom). The Russian state energy companies often use foreign trade intermediaries to siphon off much of the rents from oil and gas exports through a chain of offshore companies. One notorious example is the role of the middleman Rosukrenergo in the sale of natural gas from Russia to Ukraine in the run-up to the crisis of 2009. Rosukrenergo was created in 2004, half owned by Gazprom and half by a Swiss-based entity whose beneficial owner seems to have been the Ukrainian magnate Dmitro Firtash. After the expropriation of Yukos in 2003, its foreign trade activities were transferred to Gunvor, a trading company founded by Putin associate Gennady Timchenko in $1999 .{ }^{26}$ Five years later, it had become the world's largest oil trader. By 2007, Forbes was estimating Timchenko's

22 Thane Gustafson, Wheel of Fortune: The Battle for Oil and Power in Russia (Cambridge: Harvard University Press, 2012), 466, doi.org/10.4159/harvard.9780674068018.

23 Vitaly Yermakov, 'Russia’s Hydrocarbon Rent', Harvard University Davis Center, 9 May 2019.

24 Rosneft also acquired Severnaya Neft in 2003, Yuganskneftegas in 2004, Udmurtneft in 2006 and Bashneft in 2016. See, Nina Poussenkova, 'Rosneft. A Triple A Company' (conference paper, The Russian Corporation, Yale University, 22 May 2009). See also Valerii Panyushkin and Mikhail Zygar, Gazprom. Novoe Russkoe Oruzhie [Gazprom: New Russian weapon] (Moscow: Zakharov, 2008).

25 Anatoly Kurmanaev, 'Venezuela's Collapse Frays its Economic Ties with Moscow', New York Times, 17 June 2019. www.nytimes.com/2019/06/17/world/americas/venezuela-russia-economy.html.

26 Irina Mokrousova, 'Gennadii Timchenko: ne stolko biznesmen, stol'ko lobbist' [Not so much a businessman, as a lobbyist], Vedomosti, 21 January 2012; Catherine Belton and Neil Buckley, 'On the Offensive: How Gunvor Rose to the Top of Russian Oil Trading', Financial Times, 14 May 2008. 
wealth at US $\$ 2.5$ billion. Milov argues that gas export pipelines such as Nord Stream were not needed on either national interest or commercial grounds—since Gazprom now has excess export capacity. ${ }^{27}$ The pipelines were built to line the pockets of the construction companies owned by Putin cronies Timchenko and Arkady Rotenburg, who together have won two-thirds of Gazprom's construction contracts. ${ }^{28}$

Writing in 2008, I was cautiously optimistic that Russia could beat the resource curse. ${ }^{29}$ The Russian economy had doubled in size in the previous seven years, with significant growth in new sectors such as telecoms, retailing and construction. Russia had paid down its foreign sovereign debts (from US $\$ 150$ billion in 2000 to US $\$ 20$ billion in 2015), and through the introduction of a sovereign wealth fund in 2004 and conservative fiscal and monetary policies, it seemed to have learned how to cope with the gyrations of global oil markets.

Thirteen years on, the economic picture is far less rosy. The 2008 financial crash hit Russia very hard, and the economy never regained a sustainable growth path. ${ }^{30}$ While Russia's foreign reserves meant that it was able to avoid a collapse of the banking system, investment never returned to its pre-2008 levels, GDP growth has averaged less than 2 per cent per year and living standards have stagnated. ${ }^{31}$ Complicating the picture was the late 2014 crash, caused by a slump in the world oil price and the postCrimea sanctions, which furthered dampened Russian growth.

Russia's poor economic performance illustrates one of the central contradictions of the 'energy superpower' model. Resource-dependent economies exhibit the pathologies of the 'resource curse': exposure to global market volatility, driven by shifts in demand and the arrival of new competitors; lack of competitiveness of other sectors due to an overvalued currency; corruption; political authoritarianism; and so on. So an 'energy superpower' finds itself facing economic and political instability at home that erodes its ability to act confidently on the international stage.

27 Vladimir Milov, 'Energy Dependence', in Russia 2030 Scenarios (Washington, DC: Free Russia Foundation, 2019), 9-20.

28 Neil Buckley, 'Analyst Sackings Will Not Stop Questions for Gazprom', Financial Times, 30 May 2018.

29 Rutland, 'Russia as an Energy Superpower'.

30 Torbjorn Becker and Susanne Oxenstierna, eds, The Russian Economy Under Putin (London: Routledge, 2019).

31 IMF, 'Russian Federation Staff Report Article IV Consultation', 2 August 2019, www.imf.org/ en/Publications/CR/Issues/2019/08/01/Russian-Federation-2019-Article-IV-Consultation-PressRelease-Staff-Report-48549. 


\section{Russia's Evolution over the Past Decade}

Two important changes over the past decade have impacted our perception of Russia as an energy superpower.

\section{The Putin Factor}

The consolidation of an authoritarian regime under Vladimir Putin has defied sceptics who initially saw him as a weak, transitional leader-but also defied optimists who posited that Russia's growing middle class and rising young generation (who had no memories of the Soviet system, or even the privations of the 1990s) would demand an open and accountable government. Unfortunately, Putin's determined efforts to marginalise the political opposition, prevent a potential 'colour revolution', reassert state control over the energy sector and limit regional autonomy have all gone much further than most people would have predicted back in 2000 . Increasingly, wealth and power have been concentrated in the hands of a small inner circle of Putin cronies.

Putin's decision to return to the presidency in 2012 triggered a largescale protest movement that was put down by force, and after which the Kremlin turned to a neo-nationalist ideology to bolster its legitimacy. This ideological shift received a boost from the March 2014 annexation of Crimea-which was surprisingly popular. Putin's other military adventures, such as the war in Syria, have been much less popular domestically.

Russia's authoritarian shift has had a deleterious impact on the country's capacity to break out of its hydrocarbon dependency and build a more diverse and globally competitive economy. With Kremlin cronies continuing to engage in asset seizure and even the jailing of rivals, there is little incentive for independent capitalists, both foreign and Russian, to invest in Russian businesses. (Or more exactly, such investments exact a higher risk premium.) A sluggish and crisis-prone economy is not a stable foundation for power projection: the government is tied up in dealing with the latest fiscal or monetary crisis; and stagnant living standards mean that its popular legitimacy is waning and in need of what is delicately called 'manual control' (ruchnoe upravlenie) - that is, direct involvement by top government officials to handle local crises. 


\section{Russia's Shift to Hard Power}

In 2007, in a speech to the Munich security conference, Putin signalled a new hard line in foreign policy, lambasting the West for abandoning Russia. ${ }^{32}$ The shift may have been connected to the Y2008 problem-the fact that Putin would have to step down from the presidency in 2008. (Notably, 2007 was also the first year that photos of the shirtless Putin started to appear.)

Since then, Moscow has shown a new willingness to use military force beyond its borders. Its military interventions in Georgia 2008, Ukraine in 2014, and Syria in 2015 caught Western observers by surprise. Each operation was a success: enemy forces were defeated (without a fight, in the case of Crimea) and Russia's strategic goals were realised. This use of conventional hard power was accompanied by a panoply of techniques of 'hybrid war'-some old, some new. This ranged from the assassination of exiled spies and dissidents to intervention in Western elections through internet troll farms, email hacking and propaganda from the RT international television station.

These successes stand in sharp contrast to Russia's previous track record: humiliating defeats in Afghanistan (1989) and Chechnya (1996), only partly reversed by the bloody but ultimately victorious second Chechen war (1999-2002). The turnaround stemmed in part from the fact that Putin had used some of Russiass surging energy export revenues to rebuild its armed forces. Spending on the Russian military increased threefold in real terms $2000-10$, peaking at 4.4 per cent of GDP. ${ }^{33}$ The army underwent limited modernisation but was protected from radical reforms, and were rewarded with a prominent place in the regime's patriotic propaganda binge. Of course, the oil and gas companies also indulge in 'petroleum patriotism'. ${ }^{34}$

32 Putin was reiterating the 'Primakov doctrine', espoused by Foreign Minister Evgenii Primakov in 1996 - that Russia must block the US from exercising global hegemony. Julia Gurganus and Eugene Rumer, 'Russia’s Global Ambitions in Perspective', Carnegie Endowment for International Peace, 20 February 2019, carnegieendowment.org/2019/02/20/russia-s-global-ambitions-in-perspectivepub-78067.

33 Susanne Oxenstierna, 'A New Trend in Russia: Defense Spending', in The Russian Economy Under Putin, ed. Torbjorn Becker and Susanne Oxenstierna (London: Routledge 2019), 87-105.

34 Doug Rogers, The Depths of Russia. Oil, Power and Culture after Socialism (Ithaca: Cornell University Press, 2015), doi.org/10.7591/9781501701573; Peter Rutland, 'Petronation? Oil, Gas and National Identity in Russia', Post-Soviet Affairs 31, no. 1 (January 2015): 66-89, doi.org/10.1080/ 1060586X.2014.952537. 
The operation in Syria was risky, since there was a possibility of conflict with US forces operating in the region. As for Donbas, the jury is still out over the wisdom of Russia's intervention. The operation succeeded in establishing a de facto statelet in East Ukraine, but at the cost of driving the rest of Ukraine into the arms of the West and subjecting Russia to quite damaging sanctions, which are still in place seven years later. ${ }^{35}$ Apart from the sanctions, the West took other actions to contain Russian expansionism, such as a North Atlantic Treaty Organization (NATO) rapid reaction force for the Baltic. Given that Russia was energetically using hard power, the question of the threat of Russia's energy weapon slipped into second place. The US continues to object to the Nord Stream 2 project, but that is attributed more to its position as a rival gas supplier than a genuine security issue.

Putin's annexation of Crimea caused an immediate 20 per cent boost in his public approval rating - the Krym nash ('Crimea is ours') effect. That has faded over time..$^{36}$ In October 2014, 67 per cent of poll respondents wanted Russia to be a great power; however, by October 2018, that was down to 49 per cent, behind citizen welfare ( 51 per cent) (up from 33 per cent in 2014). ${ }^{37}$ The top priority was building a developed economy (67 per cent) and living standards (66 per cent). Thus, the main challenge to Putin's embrace of hard power is whether it is politically sustainable on the home front.

\section{Changes in Global Energy Markets}

There have been some revolutionary changes in global energy markets over the past decade that together further undercut Russia's putative role as an energy superpower.

\section{The Fracking Revolution}

The development of 3D and 4D seismology since 1980, plus new horizontal drilling techniques, led to an explosion of oil and gas production in the US. The US shift from an oil importer to an oil exporter was alarming to traditional oil producers, although, thanks to booming demand from

35 Richard Connolly, Russia's Response to Sanctions: How Western Economic Statecraft Is Reshaping Political Economy in Russia (Cambridge: Cambridge University Press, 2019), doi.org/10.1017/9781108227346.

36 'Approval Ratings', 1 June 2018, www.levada.ru/2018/06/01/rejtingi-odobreniya-2/.

37 Viktor Khamraev, 'Blagopoluchie dorozhe velichiia' [Wellbeing is more precious than greatness], Kommersant, 6 November 2018, www.kommersant.ru/doc/3792003. 
China and elsewhere, the oil price held up. (In 2013, China became the world's largest oil importer.) Kirill Dmitriyev, head of the state-backed Russian Direct Investment Fund, said that the oil price would have to go below US $\$ 40$ to drive out US shale producers, but such a price would push Russia into recession. ${ }^{38}$ Russia now needs oil at US $\$ 50$ to balance the budget (down from a US $\$ 98$ break-even point in 2014). ${ }^{39}$

Gas is a different story: the US gas price toppled from US $\$ 13 / \mathrm{mmbtu}$ in 2008 to below US\$5 since 2010. The decreased demand for LNG imports in the US meant a sharp drop in the price of gas on international markets. ${ }^{40}$ Gazprom had to cut prices and faced lawsuits challenging its long-term take-or-pay contracts, obliging it to pay US $\$ 3.2$ billion in rebates to European customers for 2012 deliveries. ${ }^{41}$ In 2012, Gazprom earned US $\$ 64$ billion from exporting $217 \mathrm{bcm}$ to Europe: in 2016, it earned only US $\$ 37$ billion, even though its export volume grew to $262 \mathrm{bcm} .{ }^{42}$ Gazprom's market cap plunged from US $\$ 350$ billion in 2008 to less than US $\$ 60$ billion today. The US is building LNG export facilities and, together with new supplies from Australia and elsewhere, this is putting downward pressure on the long-term gas price. However, while the EU demand for gas is expected to fall from 600 to $500 \mathrm{bcm}$ by 2030 , the output of the Norwegian fields will decline from 300 to $200 \mathrm{bcm}$, so the continent's dependence on gas imports will not shift. The future of gas hinges in large part on policies in response to climate change (see section below). In 2016, the EU settled its longstanding lawsuit against Gazprom, aimed at forcing it to conform to the Energy Charter and allow third-party access to its pipelines. ${ }^{43}$

Russia missed out on the seismology revolution, and has fallen behind in turbines, refining technology and offshore drilling. It urgently needs to import technology through Western oil service companies, but these have been barred by the post-Crimea sanctions. It sees itself locked into an economic war with the US-and one that it is not winning. At the Saint Petersburg Economic Forum in June 2019, Rosneft head Igor

38 'Russia Says Oil Price War with US Would be Too Costly', Reuters, 23 January 2019, www. reuters.com/article/us-davos-meeting-russia-opec/russia-says-oil-price-war-with-u-s-would-be-toocostly-idUSKCN1PH1A9.

39 Ben Aris, 'Russia's National Projects', Russia Matters, 30 May 2109, www.russiamatters.org/ analysis/russias-national-projects-economic-reboot-or-mucky-bog.

40 Thiery Bros, 'A New Narrative for Gas in Europe', Harvard University Davis Center, 10 May 2019.

41 Guy Chazan and Neil Buckley, 'A Cap on Gazprom's Ambitions', Financial Times, 6 June 2013.

42 Henry Foy, 'Russia's \$55 Bn Gamble on China's Demand for Gas', Financial Times, 3 April 2018.

43 Rachelle Toplensky, Jack Farchy and Henry Foy, 'Gazprom and Brussels Agree to Settle LongRunning Dispute', Financial Times, 26 October 2016. 
Sechin said 'the United States uses energy as a political weapon on a mass scale' and accused it of practising 'energy colonialism' with its sanctions on Iran and Venezuela. ${ }^{44}$

\section{The Rise of China}

Alarmists in the West warn of the birth of a new anti-American bloc, forged out of shared authoritarian values and antipathy to America's global leadership role. Sceptics argue that deep differences between Russia and China will prevent them from ever forging a genuine alliance, pointing to factors such as cultural distance, historical rivalry and divergent economic interests. ${ }^{45}$ And, even if such an alliance does emerge, Russia would likely be forced into the role of a junior partner.

The 2000s saw increased bilateral trade and, with the opening of a new oil export pipeline in 2009, China overtook Germany as Russia's largest trading partner in 2011.46 One branch of the East Siberia - Pacific Ocean pipeline goes to Daqing, China, while an extension runs south to the Russian port of Nakhodka for export to Japan and South Korea. Cooperation deepened after the 2008 global financial crisis, which exposed the inadequacy of the Western-led system of global governance. ${ }^{47}$ The APEC (Asia-Pacific Economic Cooperation) summit that Vladimir Putin hosted in Vladivostok in 2012 is seen as marking a 'pivot to Asia' (though Putin himself has never uttered that phrase). ${ }^{48}$ In May 2015, Putin formally agreed to coordinate the work of the Eurasian Economic Union with China's One Belt One Road initiative-which came to replace the Shanghai Cooperation Organization as the main vehicle for China's engagement with Central Asia. ${ }^{49}$

44 Dmitri Zhdanikov, 'Russia’s Sechin Accuses US of Using Energy as a Political Weapon', Reuters, 6 June 2019, www.reuters.com/article/us-russia-forum-sechin-usa/rosneft-ceo-accuses-us-of-usingenergy-as-a-political-weapon-idUSKCN1T70V0.

45 Bobo Lo, Axis of Convenience: Moscow, Beijing, and the New Geopolitics (Washington, DC: Brookings Institution, 2008).

46 Peter Havlik, 'Trade Reorientation in Russia: Will China Replace the EU?', WIIIW, 10 July 2018, wiiw.ac.at/trade-reorientation-in-russia-will-china-replace-the-eu--n-327.html.

47 Jeff Schubert, 'China's Silk Road and the EAEU', Russian Economic Reform, 5 April 2017, russianeconomicreform.ru/2017/04/chinas-silk-road-and-the-eaeu-in-sco-space/.

48 Stephen Fortescue, 'Russia's “Turn to the East”: A Study in Policy Making', Post-Soviet Affairs 32, no. 5 (2016): 423-54, doi.org/10.1080/1060586X.2015.1051750.

49 China became less interested in the Shanghai Cooperation Organization as a result of the 2015 decision-after Russian pressure-to admit India and Pakistan. See, Alexander Gabuev and Ivan Zuenko, "The "Belt and Road" in Russia: Evolution of Expert Discourse from Caution to Euphoria to Disappointment', Russia in Global Affairs, 17 January 2019, eng.globalaffairs.ru/number/The-Beltand-Road-in-Russia-Evolution-of-Expert-Discourse-19915. 
Moscow insists on seeing the relationship with China as a partnership of equals. However, China is acutely cognisant of the Soviet collapse and subsequent economic decline. Russia is trying to use military threats to restore a great power status that its demography and level of economic development do not merit. China's economy is five times that of Russia, and is moving ahead not just in low-cost manufacturing but also hightech sectors. Russian national interests may not be served if they find themselves 'falling into line' behind a rising China.

In 2009, China lent US $\$ 25$ billion to Rosneft and Transneft to develop Siberian oil supplies, and another US $\$ 25$ billion loan package was announced in 2015. For many years, Russia was reluctant to allow China equity access to oil and minerals projects, but that started to change in 2013 when CNPC bought 20 per cent of Novatek's Yamal LNG project, which reached full capacity in December 2018. In 2015, Sinopec got permission to buy 20 per cent of oil producer SIBUR, and in 2017 CEFC China Energy bought a 14 per cent stake in Rosneft for US $\$ 9$ billion. In 2012, work started on the Power of Siberia gas export pipeline that will run 3,200 km from Chayanda to Khabarovsk, where it will link with a pipeline from the gas fields in Sakhalin, and continue to the port of Vladivostok. In May 2014, Russia signed a US $\$ 400$ billion deal to supply China with $38 \mathrm{bcm}$ of gas for 30 years. The price is not known: China is thought to pay a mere US\$9 per mmbtu to Turkmenistan, and it will likely drive an equally hard bargain with Russia. ${ }^{50}$

In the 1990s, China was a major customer for Russian arms, helping to keep Russian defence plants afloat. However, in 2007 Russia denounced China for reverse engineering the Su-27 fighter, which it had been assembling under licence since 1995, and there was a six-year hiatus in arms sales. In March 2013, Moscow relented and agreed to sell China 24 Sukhoi Su-35 fighters (worth US\$2 billion) and four Amur-class submarines. In April 2015, Russia sold them 36 S-400 missile defence systems for US $\$ 3$ billion-which Beijing swiftly deployed to the South China Sea. The two countries have conducted joint peace mission military exercises since 2009 and naval drills since 2012, extending into the Mediterranean in 2014 and the South China Sea in 2016. (Russia came out in support of China after the United Nations Convention on the Law of the Sea ruled against China’s position in 2016.)

50 Jack Farchy, 'Gazprom's China Contract Offers No Protection Against Low Prices', Financial Times, 10 August 2015. 
There is also potential for rivalry as Chinese influence expands in the postSoviet space. The two countries seem to have achieved a stable division of labour in Central Asia, with China taking the lead in economics and Russia handling security issues. China overtook Russia as the region's largest trading partner in 2009. China has growing economic interests in Ukraine. It abstained in the UN vote that condemned Russia's annexation of Crimea (though it did vote for a later IMF loan to Ukraine, over Russian objections). China has also inserted itself into the race to develop the Arctic as a transport route and source of oil and gas supplies, joining the Arctic Council as an observer in 2013.

\section{The Challenge of Climate Change}

Russia reluctantly signed on to the Kyoto and Paris accords, aware that setting a target of 25 per cent carbon emissions reduction from 1990 did not require a substantial policy shift, given the collapse of Russian manufacturing in the 1990s. (As of 2014, Russian emissions were 30 per cent below their 1990 level.) Russia plans to continue making as much money as it can from exporting oil, gas and coal until the last possible moment - using more coal to fuel power plants to free up gas for export. The 2011 Fukushima accident led gas lobbyists in Europe to promote natural gas as the 'cleaner' carbon fuel, encouraging Germany and other countries to switch their power plants from coal to gas for a transitional period, until renewables and storage technology develop to the point where they can provide the bulk of electricity generation. ${ }^{51}$ In Germany, Poland and elsewhere, the gas lobby has run into the coal lobby. Since 2005, renewables in Germany have gone from 10 per cent to 40 per cent of power generation, but this has squeezed out gas not coal, which still accounts for 40 per cent. ${ }^{52}$ In contrast, the UK has halved electricity generation emissions since 2013, and will phase out coal completely by 2025 .

China has established itself as a global leader in solar and wind turbine technology. But rather than invest in conservation or renewable energy, Russia is building more atomic power plants—and has an ambitious

51 Jack Sharples, 'Europe's Largest Natural Gas Producer in an Era of Climate Change: Gazprom', in Handbook of the International Political Economy of Energy and Natural Resources, ed. Andreas Goldthau et al. (London: Palgrave, 2018) 154-71, doi.org/10.4337/9781783475636.00019.

52 Tobias Buck, 'Angela Merkl's Tarnished Legacy on the Environment', Financial Times, 29 January 2019. 
program to export them overseas. Russia has persuaded Hungary and Finland to build plants, though Bulgaria cancelled their contract after a new government came to power in 2016. Tynkkynen argues that generous subsidies for Rosatom's export program are a way to keep the military industry complex happy and share with them some of the spoils from Russia's hydrocarbon economy. ${ }^{53}$

Russian leaders have been complacent about climate change, noting some positive impacts, such as a longer growing season and the opening up of the Arctic for transport and resource extraction. Some prominent Russian scientists are climate change deniers. ${ }^{54}$ However, the reality is that climate change will have a severe impact on Russia's ecology and economy, as evidenced by the current droughts and forest fires. The melting of the permafrost will make the maintenance of infrastructure in northern regions a lot more expensive.

Tynkkynen points out that, with its vast forest reserves, Russia has the potential to be a 'green superpower', but the current political and economic system is blocking policies moving the country in that direction. ${ }^{55}$ Instead, policy is held hostage by the hydrocarbon elite who are trying to maximise short-run profits. Russia is a particular pernicious example of the potent interconnections between market forces, security concerns and climate change. ${ }^{56}$

\section{Explaining Russia's Motives}

There is a debate over the dynamics behind the role of energy in Russia's foreign policy. Some argue that Russian policy is driven by strategic concerns, with Moscow trying to use energy as a weapon to advance its political agenda. ${ }^{57}$ Conversely, there is the argument that Gazprom and the oil companies are merely seeking to maximise profits (subject to

53 Tynkkynen, The Energy of Russia.

54 Tynkkynen, The Energy of Russia, ch. 6.

55 Tynkkynen, The Energy of Russia.

56 Andrea Goldthau, Michael F. Keating and Caroline Kuzemko, 'Nexus Thinking in International Political Economy', in Handbook of the International Political Economy of Energy and Natural Resources, ed. Andrea Goldthau, Michael F. Keating and Caroline Kuzemko (London: Palgrave, 2018), 1-23, doi.org/10.4337/9781783475636.

57 Adam Stulberg, Well Oiled Diplomacy. Strategic Manipulation and Russia's Statecraft in Eurasia (Albany, NY: SUNY Press, 2008). 
political constraints) like any other commercial corporation. ${ }^{58}$ There is also a third argument - that bargaining over Ukrainian gas deliveries, or whether to build new export pipelines, is conducted by a narrow circle of individuals with close ties to Putin, who seek to maximise the flow of rents into their personal offshore bank accounts, and use the rhetoric of Russian national interest to disguise their venal machinations.

These three levels of analysis are embedded in three distinct intellectual paradigms that rarely engage directly with each other. They start with very different assumptions about how the world works, and look for very different sorts of empirical evidence to verify their claims.

The geopolitical argument is rooted in deep-seated assumptions about the structural dynamics of the international system. Russia is a Eurasian land empire whose mission is to control as much real estate as possible, extracting the resources from the occupied territories to fund the state that protects and expand said lands. This approach is compatible with the realist school of international relations (IR).

The commercial frame focuses on the micro-dynamics of corporate decision-making, including floating international loans, launching IPOs (initial public offerings) in foreign stock exchanges, concluding agreements with foreign partners and seeking arbitration in international courts. The principal actors in this model are corporate entities answering to a transnational bloc of shareholders, with only a contingent and transactional relationship to any given nation-state. It is congruent with the liberal-institutionalist IR school, and with thinkers (of both right and left) who argue that globalisation has transformed the character of IR. Third, there is the argument that Russia is a kleptocracy, run to benefit the narrow, personal interests of a small group of ruling families. Oligarchic rule is not simply a product of the disruptive transition of the 1990s, but has become an institutionalised organising structure of the Russian political regime, reproducing itself as the rising generation of oligarch children ascend to senior positions. It is journalists who have advanced the kleptocracy argument, through studies of individual oligarchs and money-laundering schemes. Few academics have tried to wrangle this material into a general theory of the functioning of the Russian state.

58 Rawi Abdelal, 'The Profits of Power: Commerce and Realpolitik in Eurasia', Review of International Political Economy 20, no. 3 (2012): 421-56, doi.org/10.1080/09692290.2012.666214. 
Marc Galeotti is the exception. ${ }^{59}$ The late Karen Dawisha's work, while influential, does not define what she means by 'kleptocracy', and the empirical material focuses on Putin's cliques in the 1990s. ${ }^{60}$

\section{A Philosophical Postscript}

At the turn of the nineteenth century, Enlightenment philosophers such as Immanuel Kant and Benjamin Constant argued that the surge in trade would lead to a decrease in interstate war, since the benefits of peaceful economic cooperation far outweighed the possible gains from aggressive war. Alas, the next century seemed to disprove that thesis, with several cases where countries went to war with their major trading partner (Germany and France, Germany and Russia, Japan and the US). In the twenty-first century we have seen a remarkable diminution in interstate war; but the economic rise of China has led to a debate over whether that means a war with the US is likely. Economic growth makes war more likely in two respects: increased wealth means more money to spend on military capacity, which can trigger an arms race with rival states; and increased economic interdependency leads to feelings of vulnerability should those resource flows be blocked (such as the US embargo of Japan in 1937). Economic growth mitigates the likelihood of war if powerful domestic lobbies emerge-business interests and/or consumers and voters-with capacity to influence decision-makers in favour of peace. This mechanism seems to work when democracies are competing with other democracies, but not with autocracies.

Russia and China are two autocratic regimes that have experienced two decades of economic growth. China, starting from a lower base, has grown twice as fast as Russia. But while China has not attacked anyone beyond its borders since 1979, Russia has waged three wars. China has significantly expanded its military capacity, but shows no interest in going to war just yet-in part because it is confident that it can achieve its goals without risky military adventures. Russia in contrast has used 'hard power' to defend its interests on its own borders and beyond.

59 Marc Galeotti, We Need to Talk About Putin. How the West Gets Him Wrong (London: Ebury Press, 2019).

60 Karen Dawisha, Putin's Kleptocracy. Who Owns Russia? (New York: Simon \& Schuster, 2015). 
This text is taken from Russian Energy Strategy in the Asia-Pacific: Implications for Australia, edited by Elizabeth Buchanan, published 2021 by ANU Press, The Australian National University, Canberra, Australia.

doi.org/10.22459/RESAP.2021.04 